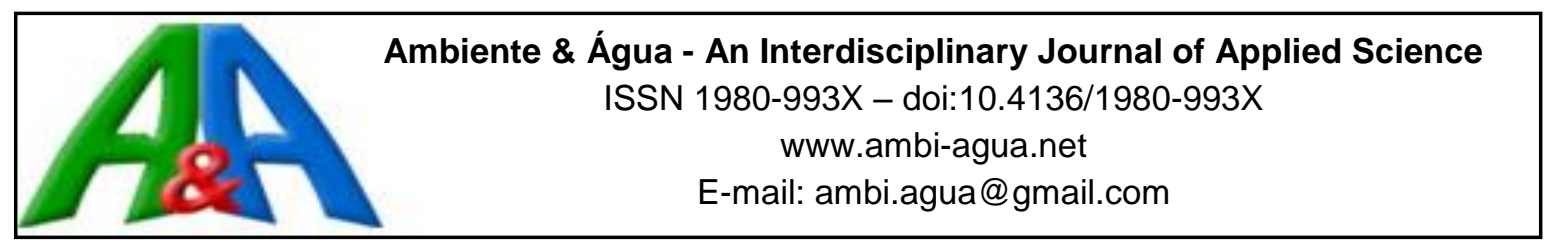

\title{
Land use and its impacts on the water quality of the Cachoeirinha Invernada Watershed, Guarulhos (SP)
}

\author{
ARTICLES doi:10.4136/ambi-agua.2131
}

Received: 09 May. 2017; Accepted: 29 Nov. 2017

\author{
Dhisney Gonçalves de Oliveira'; Reinaldo Romero $\operatorname{Vargas}^{1 *}$; Antonio Roberto Saad ${ }^{1}$; \\ Regina de Oliveira Moraes Arruda ${ }^{1}$; Fabrício Bau Dalmas ${ }^{1}$; \\ Fernanda Dall'Ara Azevedo ${ }^{2}$ \\ ${ }^{1}$ Universidade Guarulhos (UnG), Guarulhos, SP, Brasil \\ Mestrado em Análise Geoambiental. E-mail: dhisneygoncalves@yahoo.com.br, rvargas@ prof.ung.br, \\ asaad@prof.ung.br, rarruda@prof.ung.br, fdalmas@prof.ung.br \\ ${ }^{2}$ Universidade Guarulhos (UnG), Guarulhos, SP, Brasil \\ E-mail: fdallara.azevedo@gmail.com \\ *Corresponding author
}

\begin{abstract}
The urbanization process through which large urban centers have been passing has drastically affected the availability and especially the quality of water. The Cachoeirinha Invernada Watershed (CIW), located in the municipality of Guarulhos (State of São Paulo, Brazil), includes areas with different land use classes. This paper aims to correlate the spatial and temporal effects of land use and land cover on the water quality of the Cachoeirinha Invernada Watershed. In a period of 12 months and at six sampling points along the watershed, the physicochemical parameters temperature (T), $\mathrm{pH}$, turbidity (TU), total solids (TS), electrical conductivity (EC), total phosphorus (TP), biochemical oxygen demand (BOD), as well as microbiological analysis (E. coli) were measured. Water quality was assessed using a modified version (WQI $\mathrm{W}_{\mathrm{M}}$ ) of the Water Quality Index (WQI) and the Trophic State Index (TSI). The areas surrounded by urban development presented a marked worsening in water quality, with the downstream point most affected and ranked as 'POOR'. From the evaluated parameters, what contributed most to water quality degradation of the Cachoeirinha Invernada Watershed (CIW) was E. coli, followed by BOD, and TP, all parameters related to the presence of sewage in the water. The need for the construction of sewerage and waste treatment, protection and recovery of riparian forests, and environmental education regarding waste disposal are necessary to significantly improve the environmental quality of the Cachoeirinha Invernada Watershed.
\end{abstract}

Keywords: environmental degradation, eutrophication, urban waters, water pollution.

\section{Uso da terra e seus impactos na qualidade da água da bacia hidrográfica Cachoeirinha Invernada, Guarulhos (SP)}

\section{RESUMO}

O processo de urbanização pelo qual passaram os grandes centros urbanos afetou drasticamente a disponibilidade e, em especial, a qualidade da água. A bacia hidrográfica Cachoeirinha Invernada (BHCI), localizada no município de Guarulhos (Estado de São Paulo, Brasil), inclui áreas com diferentes classes de uso do solo. Este trabalho tem como objetivo 
correlacionar os efeitos espaciais e temporais do uso da terra e da cobertura do solo na qualidade da água dessa bacia hidrográfica.. Foram analisados, em um período de 12 meses e em seis pontos de amostragem na área da bacia hidrográfica, parâmetros físico-químicos como a temperatura $(\mathrm{T}), \mathrm{pH}$, turbidez (TU), sólidos totais $(\mathrm{ST})$, condutividade elétrica (CE), fósforo total (FT), demanda bioquímica de oxigênio (DBO), bem como análise microbiológica (E. coli). A qualidade da água foi avaliada usando uma versão modificada (WQIM) do Índice de Qualidade da Água (IQA) e do Índice do Estado Trófico (IET). As áreas cercadas pelo desenvolvimento urbano apresentaram um acentuado agravamento na qualidade da água, com o ponto a jusante mais afetado e classificado como 'POBRE'. A partir dos parâmetros avaliados, o que mais contribuiu para a degradação da qualidade da água da BHCI foi E. coli, seguido de DBO e FT, parâmetros esses relacionados à presença de esgoto na água. A necessidade de construção de esgoto e tratamento de resíduos, proteção e recuperação de matas ciliares e educação ambiental com foco na eliminação de resíduos são necessárias para melhorar significativamente a qualidade ambiental da bacia hidrográfica Cachoeirinha Invernada.

Palavras-chave: degradação ambiental, eutrofização, águas urbanas, poluição da água.

\section{INTRODUCTION}

The rapid growth of urban centers in the last decades has promoted disordered land occupation and use, resulting in adverse environmental transformations, in particular in large Brazilian cities (Santos, 2011). According to Ott (2004), this urbanization model, characterized by bad public and private administration, causes a variety of negative impacts to the environment, among them the lack of sanitation and consequent pollution of water bodies, which are impacts associated with urban environments. The search for a place to live, especially when it comes to the lower-income class, leads to the occupation of fragile areas and consequently to a decrease in environmental quality (Mueller, 2007). The significant encroachment of urban areas upon the natural environment have caused countless negative impacts on the quality of the urban environment, especially impacts concerning the use of water resources (Braga e Carvalho, 2003).

The watersheds have been used as units of analysis in environmental studies, because interactions between the characteristics of the physical and biotic systems in these units and a variety of land use classes are observed, which reflect in the water body quality (Botelho e Silva, 2004). Therefore, the use of water as a geoindicator of the environmental quality is possible for a hydrographic basin. The hydrographic basin is a favorable ecosystem for practical management and by means of indicators obtained from its water courses, the quantification and the estimate of how much human activity interferes in natural systems is possible (Gama, 2003).

Water quality plays a fundamental role in human life and in ecosystem health. By means of physicochemical and microbiological parameters, it is possible to estimate the environmental quality of a certain region, for instance, a hydrographic basin. To analyze water quality, several indicators are used, such as the Water Quality Index (WQI) and the Trophic State Index (TSI). WQI is one of the most-used indices in Brazil to estimate the water quality of a water body. It was developed by the National Sanitation Foundation in 1970 in the USA, and was later adapted by CETESB (Environmental Company of the State of São Paulo). It is an index composed of nine parameters particularly sensitive to contamination by domestic sewage, which explains its use, since sewage is the main source of contaminants in Brazil (ANA, 2013). TSI classifies the water bodies with respect to the trophic grade, that is, nutrient availability in water (Esteves, 2011). The main nutrient that causes eutrophication is phosphorus, which can be found in natural environments, in phosphate rocks, in the inflow of untreated domestic sewage, and associated with the use of fertilizers in agriculture (Pantano et al., 2016). TSI classifies a water 
body in six trophic classes, according to the total phosphorus concentrations in the water. The conditions favorable to eutrophication are those of a lentic environment, characterized by the presence of nutrients, high temperatures, high radiation levels, low turbidity and high residence time of water. Water bodies of lotic environments classified as eutrophic, supereutrophic or hypereutrophic rarely show eutrophication. However, it is by means of rivers and brooks that a great part of nutrients reach lakes and reservoirs (ANA, 2013; Vargas et al., 2015).

The Municipality of Guarulhos is in full urban expansion. It is not an exception when it comes to problems related to planning, which result in degradation of natural environments, induced by industries, roads, an airport, real estate development, services and significant construction, such as the installation of the northern segment of the Mário Covas Ring Highway, now finished (Andrade et al., 2008a; Mesquita, 2011; DERSA, 2016).

In face of this urban expansion, the Cachoeirinha Invernada Watershed (CIW), which is part of the Baquirivu Guaçu River Watershed (BGRW), was selected, with the aim of correlating the spatial-temporal effects of land use and cover on water quality by means of physicochemical and microbiological parameters.

\section{MATERIALS AND METHODS}

\subsection{Location and characteristics of the study area}

The Municipality of Guarulhos is located in the northern portion of the São Paulo Metropolitan Region (SPMR). According to the Brazilian Institute of Geography and Statistics, it is the second major city of the State of São Paulo, with a population of approximately 1.3 million inhabitants distributed in an area of $320 \mathrm{~km}^{2}$ (IBGE, 2013).

The study area is located in the northern portion of Guarulhos (GRAÇA, 2007; Figure 1). The relief in this region is very steep, with expressive elevations represented by the Itaberaba and Bananal ridges. Metamorphic and igneous rocks predominate and the drainage shows a dendritic pattern, constituting watershed zones. Regarding land occupation, there is a predominance of rural classes, and intensive transformation resulting from the implantation of the northern segment of the Mario Covas Ring Highway and of new neighborhoods (Saad et al., 2013), characterized by a low-income population and deficiency in urban infrastructure (Mesquita, 2011).

According to Andrade et al. (2008b) and Miranda et al. (2009), Guarulhos has an average annual temperature between $18^{\circ} \mathrm{C}$ and $19^{\circ} \mathrm{C}$, the lowest monthly average is below $15^{\circ} \mathrm{C}$, and in the hottest months (summer) the average varies between $23^{\circ} \mathrm{C}$ and $24^{\circ} \mathrm{C}$. The annual rainfall of the municipality of Guarulhos is between 1,250 and 1,500 $\mathrm{mm}$. 

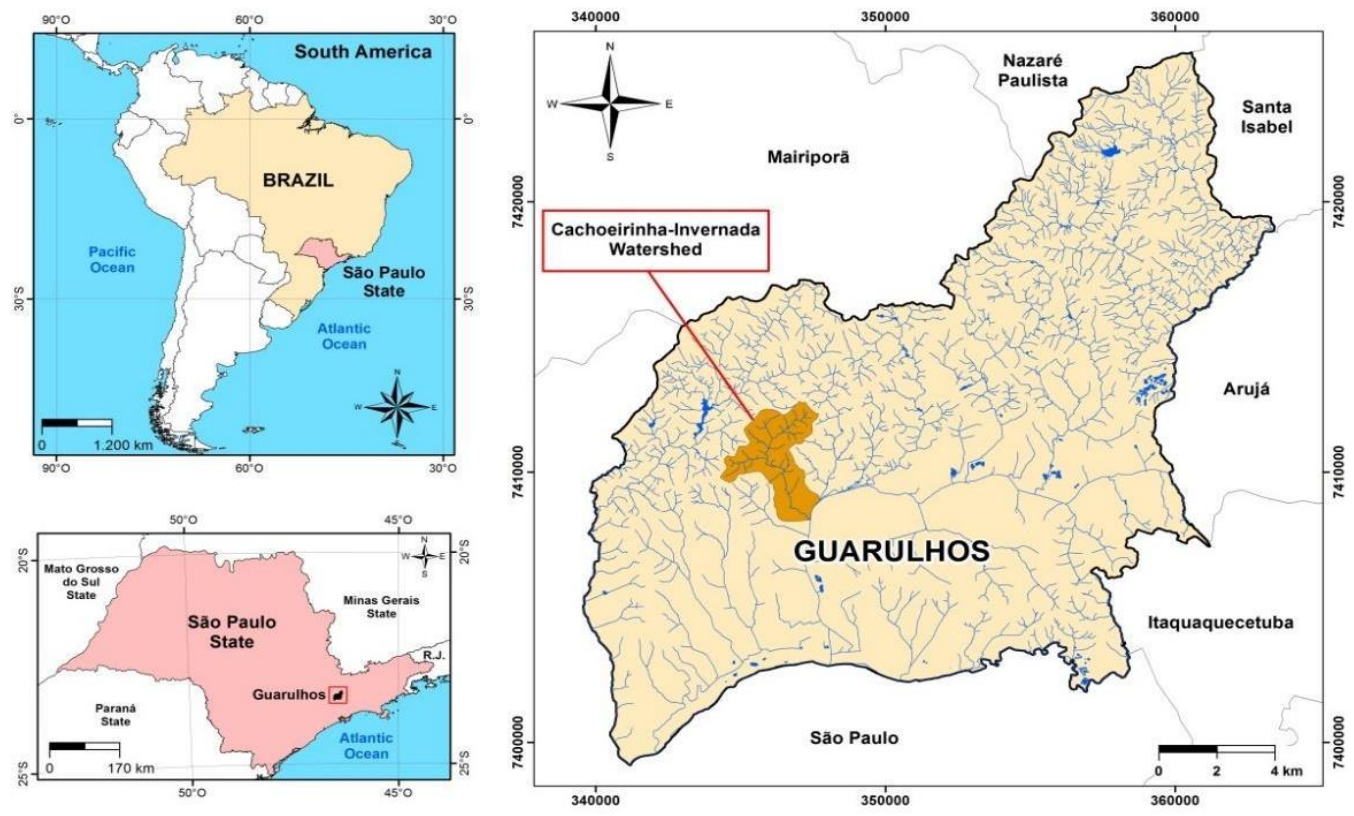

Figure 1. Location of Cachoeirinha Invernada Watershed, Guarulhos (SP).

\subsection{Preparation of the land use and occupation map}

The land use and occupation map was prepared in two phases. In the first, remote sensing techniques were applied, including photo interpretation and recognition of homogeneous land cover. The second phase involved mapping by means of digitalization of layers on the orbital image.

An image taken by Pleiades on August $3^{\text {rd }}, 2014$ was used for photo interpretation, with a spatial resolution of $50 \mathrm{~cm}$. The Object-Oriented Combination technique, which is an important tool for the effective classification and mapping of land use classes, was adopted in this study (Duveiller et al., 2008). This phase focused on the characterization of visual aspects of the observed objects, which allows their recognition and identification. Therefore, the following parameters of the objects present in the Pleiades scene were considered: color, texture, geometry (shape), size, orientation and spatial distribution.

The objects were analyzed regarding the occupation pattern by means of parameters related to occupation density (number of lots per area unit), ordering (street, block and lot layouts), and stage of occupation (consolidation level), according to criteria established by Tominaga et al. (2004).

Digitalization was performed after the vectorialization of the objects classified by the Object-Oriented Combination technique. Considering the scale of the project $(1: 10,000)$, the minimum polygon size was defined adopting the IBGE (2013) criterion of $50 \mathrm{x} 50 \mathrm{~m}^{2}$ $\left(5 \times 5 \mathrm{~mm}^{2}\right)$. All the procedures were developed using ArcGIS, Version 10 (ESRI, 2013).

\subsection{Water sampling and analysis}

For the analysis of the CIW water quality, six points were selected for sampling (P1 to P6), which took place bimonthly from September 2015 to August 2016 (12-month period), resulting in six sample-collecting campaigns. The selection of sampling points (Figure 2) was based on the coverage (size of the drainage surface), and of regions distinguished by types of land use. In the northern part, more preserved and natural areas predominate, whereas in the southern part, mostly urbanization predominates. Point P1 (23'23'31.55' S and 46 $29^{\circ} 48.22^{\prime \prime}$ W), with an altitude of $935 \mathrm{~m}$, is located upstream along the Invernada Brook, close to the basin limit in the northeastern portion, which is also a forested area. Point P2 (23 $23^{\prime} 56.94$ ' $\mathrm{S}$ and $46^{\circ} 30^{\prime} 07.53^{\prime \prime} \mathrm{W}$ ), with an altitude of $791 \mathrm{~m}$, is located in the margin of a small, artificial lake. 
Point P3 (2324'10.96' $\mathrm{S}$ and 46 $\left.36^{\circ} 31.27^{\prime} ' \mathrm{~W}\right)$, with an altitude of $782 \mathrm{~m}$, is located in the Taquara do Reino Brook (a tributary of the Invernada brook) and is influenced by intensive

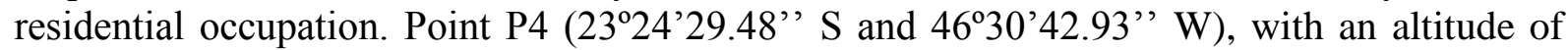
$778 \mathrm{~m}$, is located in a tributary of the Cachoeirinha Brook, upstream from the intersection with the Invernada Brook, on the Recreio São Jorge road, in an area with more preserved vegetation.

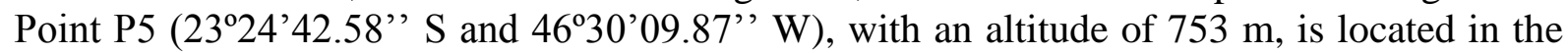
Cachoeirinha Brook, downstream from the intersection with the Invernada Brook, with predominance of urban occupation and exposed soil. Point P6 $\left(23^{\circ} 25^{\prime} 32.23^{\prime \prime} \mathrm{S}\right.$ and $46^{\circ} 29^{\prime} 51.42$ ' ' W), with altitude of $742 \mathrm{~m}$, is located in the urban area, close to the CIW outlet, approximately $470 \mathrm{~m}$ downstream from the Baquirivu Guaçu River.

The samples were collected according to the National Guide for Collecting and Preservation of Samples (ANA e CETESB, 2011) and were analyzed in the field and in the laboratory. The field determinations were hydrogen potential $(\mathrm{pH})$ (portable Digimed DM-2 pHmeter), dissolved oxygen (DO) (Digimed DM-4 oximeter), turbidity (TU) (Quimis Q 279P turbidity meter), electrical conductivity (EC) and temperature (T) (Digimed DM-3 conductivity meter coupled to a digital thermometer). In the laboratory total phosphorus (TP), total solids (TS) and Escherichia coli (E. coli) were analyzed according to the Standard Methods for the Examination of Water and Wastewater (APHA, 2012). The biochemical oxygen demand (BOD) was determined using BOD electronic analyzers and the manometric method (VELP, 2016). The results of the analyses made in the field and in the laboratory were checked by comparing them with standards established by CONAMA Resolution 357/2005 (CONAMA, 2005) and with Class 3 water bodies, according to the classification in State Decree 10755 (São Paulo, 1977). To evaluate the effect of seasonality on the performed analyses, the data were separated into the dry periods $(n=3)$, for the months of May, August and September, and the rainy season $(n=3)$, for the months of January, March and November. The data were treated applying descriptive statistics (Box-plot, mean and standard deviation). The method developed by Posselt and Costa (2010) for Pareto or ABC analysis applied to water quality was used to classify the parameters analyzed in relation to the decrease in the WQI value. The analyzed parameters are classified in decreasing order and the higher the percentage of the parameter, the greater the contribution in the decrease of the WQI.

\subsubsection{The Modified Water Quality Index - WQIM}

Besides the water quality index WQI, a modified WQI (WQI $\mathrm{I}_{\mathrm{M}}$ ), as proposed by RIBEIRO (2016), was obtained. No substantial differences were observed in water quality classification by the $\mathrm{WQI}_{\mathrm{M}}$ and the WQI (CETESB, 2013). In this manuscript, $\mathrm{WQI}_{\mathrm{M}}$ values will be reported as WQI. According to CETESB (2013), WQI is a number that varies from 0 to 100 , classifying water quality in the following categories: EXCELLENT $(79<\mathrm{WQI} \leq 100)$; GOOD $(51<\mathrm{WQI} \leq 79)$; AVERAGE $(36<\mathrm{WQI} \leq 51)$; BAD $(19<\mathrm{WQI} \leq 36)$ and $\mathrm{POOR}(\mathrm{WQI} \leq 19)$.

\subsubsection{Trophic State Index - TSI}

To calculate the Trophic State Index (TSI), a method adapted by Lamparelli (2004) was used, in which only total phosphorus values are used for rivers. IET values are classified according to trophic state classes established by Lamparelli (2004): Ultra Oligotrophic $(\mathrm{TSI} \leq 47)$; Oligotrophic $(47<\mathrm{TSI} \leq 52)$; Mesotrophic $(52<\mathrm{TSI} \leq 59)$; Eutrophic $(59<\mathrm{TSI} \leq 63)$; Supereutrophic $(63<\mathrm{TSI} \leq 67)$; and Hypereutrophic $(\mathrm{TSI}>67)$.

\section{RESULTS AND DISCUSSION}

The Cachoeirinha Invernada Watershed encompasses an area of $7.6 \mathrm{~km}^{2}$ and includes zones with both rural and urban characteristics, as can be seen in the land use and occupation 
map (Figure 2). The most representative class is the forested area, covering $40.61 \%$ of the total area. In decreasing order, the classification is as follows: residential urban use - 38.92\%; reforesting $-13.02 \%$; exposed soil $-1.27 \%$; sheds and yards (parking of equipment) $-0.88 \%$; grassland $-0.63 \%$; small farms $-0.54 \%$; and unconsolidated residential urban use $-0.88 \%$.

Water samples from the Cachoeirinha Invernada Watershed were collected from September 2015 to August 2016, and the results of the physical, chemical and microbiological parameters are presented in Figure 3.

Point P1 is located further upstream along the Invernada Brook, close to the CIW limit in the northeastern most portion, which is mostly covered by forest. There is a dirty road close to $\mathrm{P} 1$ and signs of anthropic influence are evidenced by the noticeable presence of certain forms of residues. The best values for the parameters analyzed in this study were found at P1, the region covered by natural vegetation. Several authors, who also attest that the most wellpreserved areas supply water of good quality (Pereira et al., 2016; Carvalho et al., 2016; Vargas et al., 2015), obtained similar results. These results indicate good water quality in P1, corroborating the land use map, which classified this portion of the basin as a forested area. Despite being in a better-preserved area, high $E$. coli concentrations were recorded at $\mathrm{P} 1$, which can be explained by the circulation of warm-blooded animals and the easy access of people.

At point $\mathrm{P} 2$, which is also located in a vegetated area, the anthropic interference is more intense when compared to point P1, due to the proximity to the Mário Covas Ring Highway and to small agricultural farms. E. coli and BOD values were higher than those obtained for point $\mathrm{P} 1$, indicating fecal contamination.

Point P3 was characterized as a site affected by significant anthropic activity. It is located in the Taquara do Reino Brook (tributary of the Invernada brook) in the Novo Recreio neighborhood, where residential occupation is intensive, with no proper urban infrastructure and predominance of dirt roads (Mesquita, 2011; Sato et al., 2011). These characteristics led to significant variations in the parameters, such as decrease in DO and high $E$. coli, TP and BOD concentrations. Of the first three points (Invernada Brook), P3 is the one that presented the worst water quality.

Electrical conductivity expresses the capacity of water to conduct electrical current, and is dependent on the concentrations of the ions present in it. Several authors have reported the use of electrical conductivity in the assessment of the impact caused by pollutants in aquatic environments, such as rivers (Thompson et al., 2012; Uwidia e Ukulu, 2013; Vargas et al., 2015) and lakes (Das et al., 2006; Costa e Henry, 2010). When measuring the electrical conductivity values along CIW, it may be observed that, besides being a fast and efficient method, it is an efficient indicator of contamination caused by domestic effluents. Vargas et al. (2015) assessed the water quality of the Taquara do Reino hydrographic basin, which is a CIW sub-basin, using various physicochemical and microbiological parameters. The authors found out that in the watershed the water quality was excellent, whereas along its course the water quality worsened with the discharge of in natura sewage. Similar results were obtained for point P3, significantly affected by anthropic action. It coincides with the outlet of the Taquara do Reino watershed, yielding high BOD values, decrease in DO, high TP and E. coli values, which are parameters characteristic of sewage contamination (Von Sperling, 2005). The high turbidity and total solids values obtained for point P3 are explained by the discharge of untreated sewage and the fact that it is a steep region with landslide-prone areas, where erosion and environmental degradation contribute to the inflow of solids to water bodies (Mesquita, 2011; Sato et al., 2011). 


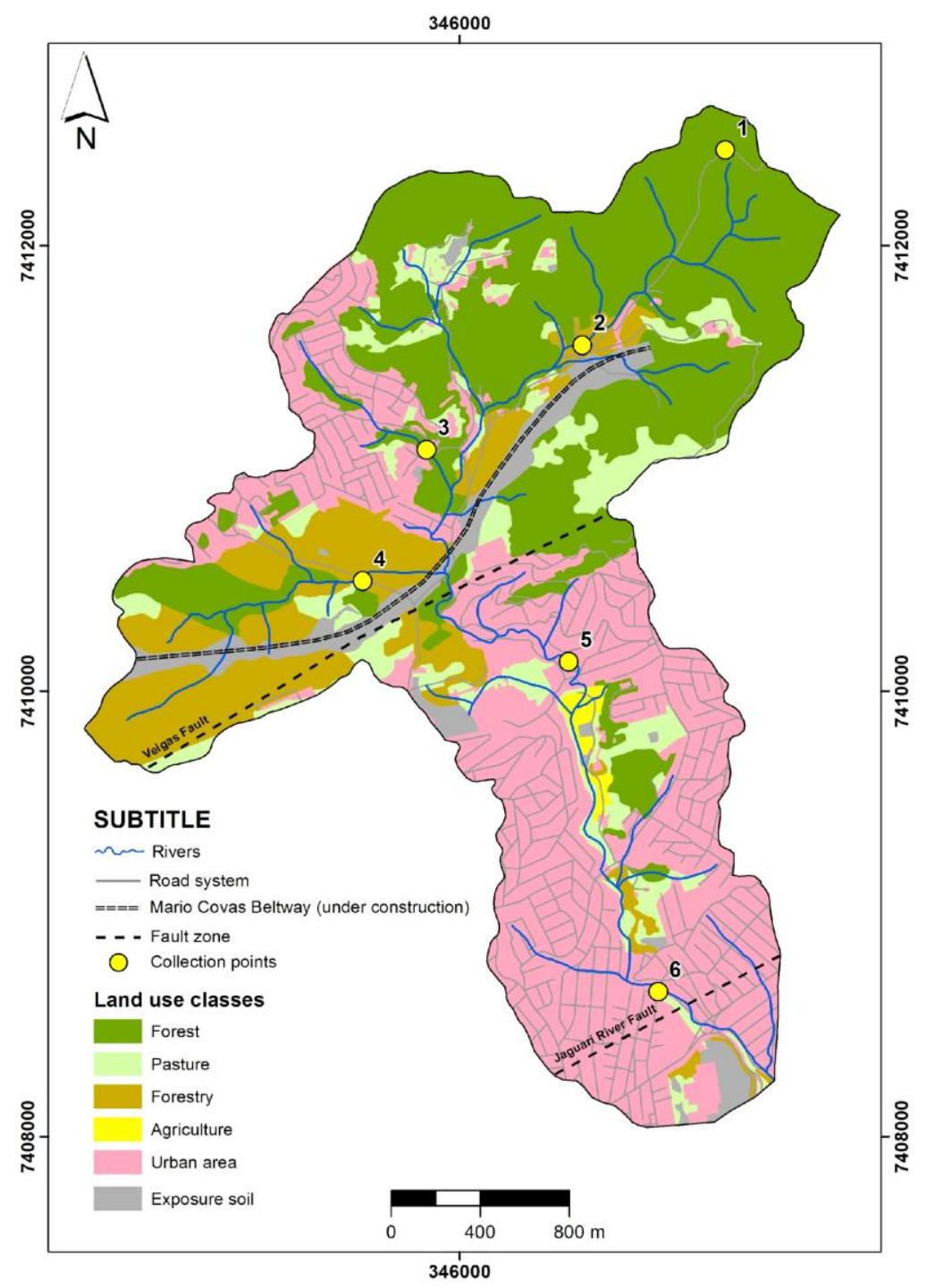

Figure 2. Map of land use and occupation classes in the Cachoeirinha Invernada Watershed, together with the water sampling points. 



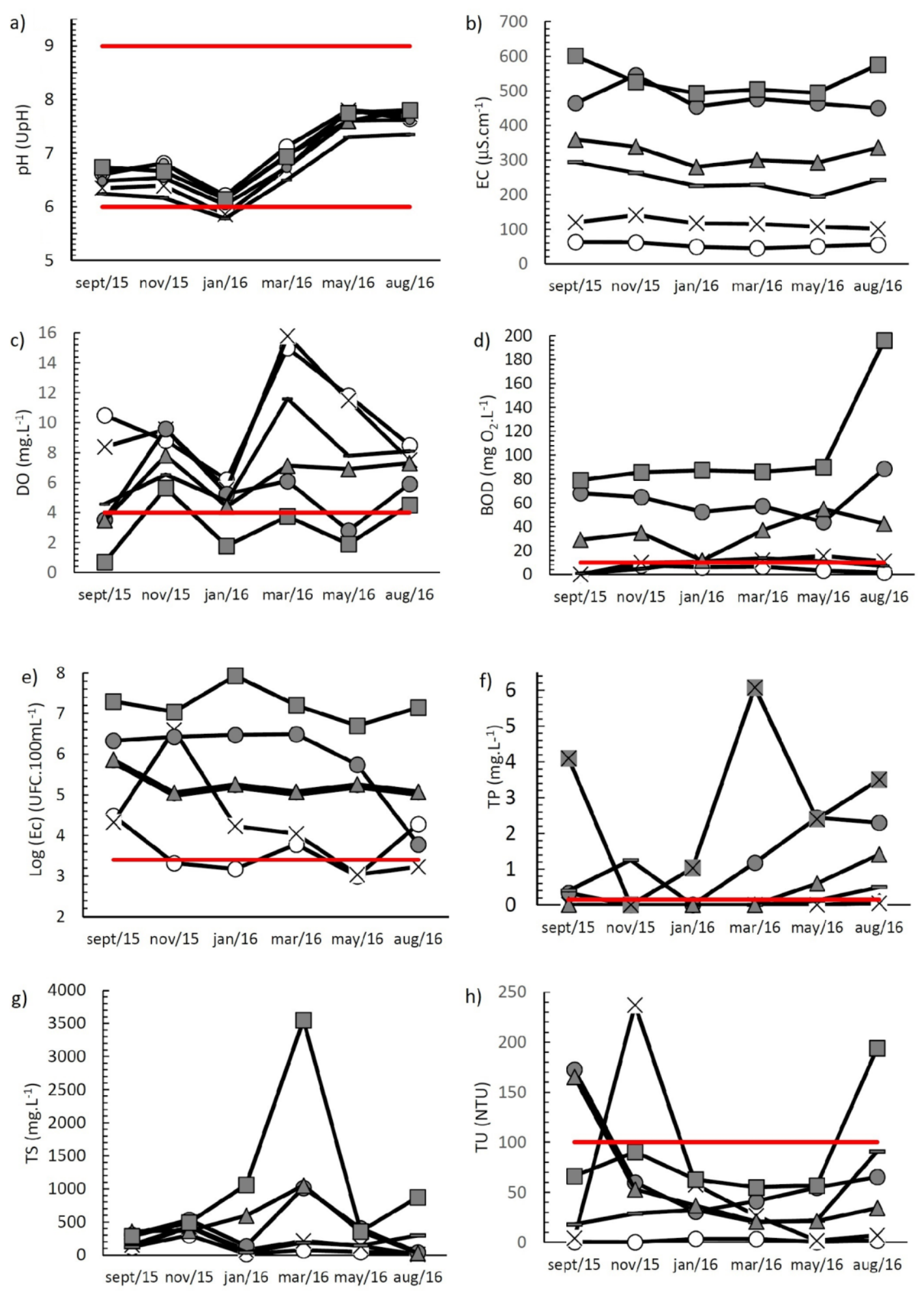

Figure 3. Physicochemical and microbiological parameters of the Cachoeirinha Invernada Watershed waters from September 2015 to August 2016 and CONAMA 357/05 limits for Class 3. Legend: a. $\mathrm{pH}=$ Hydrogen Ionic potential, b. $\mathrm{EC}=$ electrical conductivity, $\mathrm{c} . \mathrm{DO}=$ dissolved oxygen, $\mathrm{d}$. BOD = biochemical oxygen demand, e. $\log ($ E.coli $)=\log ($ Escherichia coli $)$, f. TP $=$ Total Phosphorus, g. TS $=$ Total Solids, h. TU = turbidity. 
Point P4 is located in a tributary of the Cachoeirinha Brook, upstream from the intersection with the Invernada Brook on the Recreio São Jorge road. Differently from point P3, point P4 is located in a more-preserved area, where vegetation (pasture/riparian forest) and reforestation (silviculture) predominate, but it is under anthropic influence. It yielded high E. coli and TP values for a Class 3 water body, but they are lower than those obtained for point P3. DO and BOD values are below the limits established by CONAMA Resolution 357/05. Located in an area of both natural riparian forest and reforestation, drainage is influenced by the ring highway works. However, total solids and turbidity values are also below the limits established by the legislation in force. The Pareto analysis for point P4 indicates that fecal contamination contributes with 53\% and both TP and BOD with $16 \%$ each to the deterioration of the water quality.

Points P5 and P6, inserted in the most urbanized areas of CIW and downstream from the intersection between the Invernada and Cachoeirinha Brooks, are sites that underwent major transformations, in particular point P6. Soil imperviousness caused by urbanization greatly contributes to the degradation of the water bodies by the discharge of nutrient and organic matter, as well as diffuse contaminants contained in the surface runoff (Tucci, 2008; Campos, 2011).

Point P6 is the only sampling point of the southern portion of CIW, where urbanization and anthropic activities predominate. It is located close to the CIW outlet, approximately 470 $\mathrm{m}$ upstream from the Baquirivu Guaçu River. From points P5 to P6, the land use classes change, with residential class prevailing on one of the margins of the water body and other classes, such as agriculture, exposed soil and vegetation (countryside) on the other margin. Point P6 yielded the highest electrical conductivity values, as water percolates both urbanized and cultivation areas, the latter contributing to the inflow of ionic species via fertilizers. Moura et al. (2010) explain that high concentrations of ions are related to the characteristics of the watershed and to the inflow of products used as inputs by industrial and agricultural sectors and domestic sewage.

The microbiological analyses revealed high E. coli concentrations at points P5 and P6. The Pareto analysis showed that at point P6 the E.coli concentrations exceeded the maximum limit of $1.21 \times 10^{6} \%$ established by the legislation in force. The results of the microbiological analyses recorded an increase in the $E$. coli concentration along the watershed, similarly to the other parameters, confirming that the deterioration of the water quality is a function of the different land use classes.

In order to evaluate the effect of seasonality, the results were separated into dry and rainy seasons (Table 1). The characteristic temperatures of the Guarulhos region, lower temperatures in the drier periods and higher temperatures in the rainy season, can be observed in Table 1.

The values of $\mathrm{pH}$ in the rainy season had a decrease, that is, the waters were more acidic. Similar results were observed by Grieco et al. (2017), Purandara et al. (2012) and Bayram et al. (2013) and this decrease in $\mathrm{pH}$ is attributed to the increase of organic matter and other wastes carried by the rains.

The BOD and TP parameters in the areas near points P1, P2 and P4 that have vegetative cover did not present large differences between the dry and rainy seasons, but the most urbanized points, such as P3, P5 and P6, show higher values for dry seasons, indicating that in the rainy season the dilution of the pollutants occurs, due to the waterproofing of the soil.

The DO parameter presented higher values in the rainy season, with the only exception being point $\mathrm{P} 1$, which did not have significant alteration. This increase of $\mathrm{DO}$ in the rainy season is justified by increased of the velocity of the water flow due to the rains, which exerts an influence on the concentration of DO in the water. The increase of water flow causes the increase of the turbulence, of aeration and, consequently, the solubility of the oxygen (Krupek et al., 2008). 
The total solids (TS) in the rainy season presented higher values, with more significant differences for the points P2, P3, P5 and P6. The most preserved points, P1 and P4, presented small variation between the rainy and dry periods. Point P2, due to the works of the Mário Covas Ring Highway and constant mass movement in the region, led to the silting process near the point of collection. The other points in urban areas (P3, P5 and P6) presented higher values in rainy season due to soil sealing and surface runoff. Ríos-Villamizar et al. (2011), De Azevedo Lopes and Magalhães Júnior. (2010), also observed these higher values of total solids in the rainy season.

Regarding the analysis of water quality in terms of the water quality index, the inflow of pollutants due to the lack of basic sanitation is evident. The modified water quality index (WQI) along the basin, calculated as shown in Figure 4, shows that the mean water quality during the 12-month sampling period was GOOD only at point P1. At point P2, also located in a wellpreserved region, the mean water quality was AVERAGE, and WQI oscillated from GOOD to $\mathrm{BAD}$, indicating the beginning of the environmental degradation process. 
Table 1. Mean values and standard deviation of the physicochemical and microbiological water parameters in the dry and rainy periods in the Cachoeirinha Invernada Watershed from September 2015 to August 2016 and CONAMA 357/05 limit.

\begin{tabular}{|c|c|c|c|c|c|c|c|c|c|}
\hline \multicolumn{10}{|c|}{ Dry season } \\
\hline Sampling points & $\mathrm{pH}(\mathrm{upH})$ & $\mathrm{T}\left({ }^{\circ} \mathrm{C}\right)$ & TP $\left(m g . L^{-1}\right)$ & $\begin{array}{c}\log (\mathrm{Ec}) \\
\left(\mathrm{UFC} .100 \mathrm{~mL}^{-1}\right)\end{array}$ & $\begin{array}{c}\text { DO } \\
\left(\mathrm{mg} . \mathrm{L}^{-1}\right)\end{array}$ & $\begin{array}{c}\mathrm{BOD} \\
\left(\mathrm{mg} \mathrm{O}_{2} \cdot \mathrm{L}^{-1}\right)\end{array}$ & $\begin{array}{c}\mathrm{EC} \\
\left(\mu \mathrm{S} . \mathrm{cm}^{-1}\right)\end{array}$ & TU (NTU) & TS $\left(\mathrm{mg} . \mathrm{L}^{-1}\right)$ \\
\hline $\mathrm{P} 1$ & $7.4 \pm 0.6$ & $13.2 \pm 2.3$ & $0.04 \pm 0.05$ & $4.2 \pm 4.2$ & $10.3 \pm 1.7$ & $2 \pm 2$ & $57 \pm 6$ & $1 \pm 1$ & $68 \pm 48$ \\
\hline $\mathrm{P} 2$ & $7.3 \pm 0.8$ & $14.4 \pm 3.1$ & $0.02 \pm 0.02$ & $3.9 \pm 4.1$ & $9.1 \pm 2.1$ & $9 \pm 8$ & $110 \pm 9$ & $4 \pm 3$ & $100 \pm 80$ \\
\hline P3 & $7.3 \pm 0.8$ & $16.8 \pm 2.1$ & $1.69 \pm 1.18$ & $6.0 \pm 6.0$ & $4.1 \pm 1.6$ & $67 \pm 22$ & $459 \pm 8$ & $98 \pm 65$ & $253 \pm 189$ \\
\hline $\mathrm{P} 4$ & $7.0 \pm 0.6$ & $15.2 \pm 3.3$ & $0.34 \pm 0.19$ & $5.5 \pm 5.5$ & $6.8 \pm 2.0$ & $6 \pm 5$ & $243 \pm 50$ & $44 \pm 41$ & $189 \pm 96$ \\
\hline P5 & $7.2 \pm 0.7$ & $16.6 \pm 3.4$ & $0.67 \pm 0.70$ & $5.5 \pm 5.5$ & $5.9 \pm 2.1$ & $42 \pm 13$ & $329 \pm 34$ & $74 \pm 80$ & $249 \pm 190$ \\
\hline P6 & $7.4 \pm 0.6$ & $18.3 \pm 4.1$ & $3.33 \pm 0.86$ & $7.1 \pm 6.9$ & $2.4 \pm 1.9$ & $122 \pm 64$ & $557 \pm 56$ & $106 \pm 77$ & $506 \pm 322$ \\
\hline \multicolumn{10}{|c|}{ Rainy season } \\
\hline Sampling points & $\mathrm{pH}(\mathrm{upH})$ & $\mathrm{T}\left({ }^{\circ} \mathrm{C}\right)$ & $\mathrm{TP}\left(\mathrm{mg} \cdot \mathrm{L}^{-1}\right)$ & $\begin{array}{c}\log (\mathrm{Ec}) \\
\left(\mathrm{UFC} .100 \mathrm{~mL}^{-1}\right)\end{array}$ & $\begin{array}{c}\text { DO } \\
\left(\mathrm{mg} . \mathrm{L}^{-1}\right)\end{array}$ & $\begin{array}{c}\mathrm{BOD} \\
\left(\mathrm{mg} \mathrm{O}_{2} \cdot \mathrm{L}^{-1}\right)\end{array}$ & $\begin{array}{c}\mathrm{EC} \\
\left(\mu \mathrm{S} . \mathrm{cm}^{-1}\right)\end{array}$ & TU (NTU) & $\mathrm{TS}\left(\mathrm{mg} \cdot \mathrm{L}^{-1}\right)$ \\
\hline $\mathrm{P} 1$ & $6.7 \pm 0.5$ & $20.4 \pm 0.3$ & $0.01 \pm 0.00$ & $3.5 \pm 3.4$ & $10.0 \pm 4.5$ & $7 \pm 1$ & $52 \pm 9$ & $2 \pm 2$ & $132 \pm 150$ \\
\hline $\mathrm{P} 2$ & $6.3 \pm 0.4$ & $22.0 \pm 0.4$ & $0.01 \pm 0.00$ & $6.1 \pm 6.4$ & $10.3 \pm 5.2$ & $11 \pm 1$ & $124 \pm 14$ & $107 \pm 114$ & $240 \pm 178$ \\
\hline $\mathrm{P} 3$ & $6.6 \pm 0.4$ & $22.1 \pm 1.2$ & $0.40 \pm 0.68$ & $6.5 \pm 5.3$ & $7.0 \pm 2.3$ & $58 \pm 6$ & $493 \pm 47$ & $44 \pm 15$ & $564 \pm 440$ \\
\hline $\mathrm{P} 4$ & $6.2 \pm 0.4$ & $21.6 \pm 1.1$ & $0.42 \pm 0.72$ & $5.1 \pm 4.5$ & $7.6 \pm 3.6$ & $10 \pm 5$ & $239 \pm 21$ & $27 \pm 6$ & $216 \pm 194$ \\
\hline P5 & $6.4 \pm 0.4$ & $22.2 \pm 1.2$ & $0.01 \pm 0.00$ & $5.1 \pm 4.6$ & $6.4 \pm 1.8$ & $28 \pm 14$ & $306 \pm 30$ & $37 \pm 16$ & $672 \pm 349$ \\
\hline P6 & $6.6 \pm 0.4$ & $23.5 \pm 2.2$ & $2.37 \pm 3.25$ & $7.6 \pm 7.6$ & $4.0 \pm 1.9$ & $86 \pm 1$ & $508 \pm 17$ & $69 \pm 19$ & $1702 \pm 1626$ \\
\hline $\begin{array}{c}\text { CONAMA } \\
357 / 05 *\end{array}$ & 6.0 to 9.0 & n.e. & $\max .0 .15$ & $\max 3.4$ & $\min .4 .0$ & $\max .10$ & n.e. & $\max .100$ & n.e. \\
\hline
\end{tabular}

Legend: $\mathrm{pH}=$ Hydrogen Ionic potential, $\mathrm{T}$ - Temperature, $\mathrm{TP}=$ Total Phosphorus, $\log (\mathrm{E} . \mathrm{c})=\log ($ Escherichia coli $)$, DO = dissolved oxygen, $\mathrm{BOD}=$ biochemical oxygen demand, $\mathrm{EC}=$ electrical conductivity, $\mathrm{TU}=$ turbidity, $\mathrm{TS}=$ Total Solids, .e. - not established. $*$ Class 3. 
The presence of a natural riparian forest close to point $\mathrm{P} 4$ does not lessen the impacts caused by anthropic activity, as the mean water quality given by WQI was BAD, varying from AVERAGE to BAD. For points P3 and P5, the mean classification was BAD, oscillating between BAD to POOR. Point P6, which is the CIW outlet to the Baquirivu-Guaçu River, and has water classified as POOR, reflecting the disordered urban occupation and lack of basic sanitation in CIW.

The WQI in the dry period for points P1 (60), P2 (56) and P4 (35) were higher than those observed in the rainy season, P1 (56), P2 (37) and P4 (33). However, the WQIs in the rainy season for points P3 (22), P5 (27) and P6 (15) were higher than the WQIs in the dry period, P3 (16), P5 (20) and P6 (11). For the most urbanized points, P3, P5 and P6, the WQI values were better in the rainy season, due to the effect of soil sealing and dilution of pollutants. Andrietti et al. (2016) studying the waters of the Caiabi River (MT, Brazil) described that the presence of riparian forest and vegetation cover aid in the improvement of the WQI and do not present great variation with the seasonality.



Figure 4. WQI of the Cachoeirinha Invernada Watershed from September 2015 to August 2016.

The main sources of phosphorus to the aquatic environment are rocks, domestic sewage and nonpoint agricultural sources (Pompêo and Moschini-Carlos, 2003). The presence of phosphorus in high quantities leads to the eutrophication of water bodies (Esteves, 2011). In lotic environments, high phosphorus and low chlorophyll concentrations can be found, but chlorophyll may not even be detected, due to the great relation between the water volume and the region of the margins, as well as the high water flow (Farage et al., 2010; Saad et al., 2013). Therefore, the Trophic State Index (TSI), because of the steep relief and high water flow in CIW, was calculated using the total phosphorus concentration only.

The conditions of the CIW brooks can be characterized as oligotrophic at points P1 and P2 during the 12-month sampling period, which correspond to the most favorable environmental conditions in CIW, with clean water bodies and with no undesirable interferences (presence of nutrients) when it comes to the use of the water. Point P3 is characterized by a super eutrophic condition, as obtained by Vargas et al. (2015), indicating anthropic activity with undesirable impacts on water quality. A eutrophic state class was obtained for point P4, with traces of anthropic interferences in the vicinity, but still preserving good environmental conditions. The trophic index at point P5 was favorable, because, even if located in an urbanized region, a 
mesotrophic state class was indicated. The great number of springs on the left margin helped maintain nutrient concentrations at acceptable levels, enabling the development of small fish species. Point P6 was classified as hypereutrophic, because the CIW waters cross large areas of the consolidated urban region, contributing with water contaminated by high concentrations of organic matter and nutrients to the Baquirivu Guaçu River.

\section{CONCLUSION}

In face of the water crisis that occurred in Southeastern Brazil from 2014 to 2016, the Municipality of Guarulhos, because of its significant volumes of water for consumption, could contribute in a more effective way to the production and supply of water of quality to the São Paulo Metropolitan Region. However, when assessing the quality of the CIW waters, the present study detected a considerable water decrease, as the natural water system undergoes anthropic interferences.

It became evident in this study that the high E. coli, BOD and TP concentrations, resulting from the lack of sewerage and sewage disposal either on soil or directly into water bodies, are predominant factors leading to the degradation of water quality. Regarding the limits established by CONAMA 357/05 (CONAMA, 2005), even for Class 3 water bodies, several physicochemical and microbiological parameters exceeded such limits, in particular the microbiological parameter.

Temporal influence on water quality was observed in a more significant way for the urbanized areas. The preserved areas that present a riparian forest and vegetation cover were very close values for the analyzed parameters and consequently the WQI values.

Preventive measures, such as protection and recovery of natural riparian forests, sewage collecting and treatment in the CIW urban areas by means of wastewater treatment plants, and environmental education focusing on disposal of urban waste, will certainly contribute to a significant improvement of the CIW environmental quality.

\section{ACKNOWLEDGMENTS}

To FAPESP (São Paulo Research Foundation) for the financial support to Project 2015/05069-4. Also, thank you to Patricia Bulbovas for your constructive evaluation of the manuscript.

\section{REFERENCES}

AGÊNCIA NACIONAL DE ÁGUAS - ANA (Brasil); COMPANHIA AMBIENTAL DO ESTADO DE SÃO PAULO - CETESB. Guia nacional de coleta e preservação de amostras: água, sedimento, comunidades aquáticas e efluentes líquidos. São Paulo: CETESB; Brasília: ANA, 2011.

AGÊNCIA NACIONAL DE ÁGUAS - ANA (Brasil). Conjuntura dos recursos hídricos no Brasil: 2013. Brasília: ANA, 2013.

ANDRADE, M. R. M.; OLIVEIRA, A. M. S. Expansão urbana e problemas geoambientais do uso do solo em Guarulhos. In: OMAR, E. E. H. (Org.). Guarulhos tem História: questão sobre história natural, social e cultural. São Paulo: Ananda Gráfica e Editora, 2008a. p. $47-55$.

ANDRADE, M. R. M.; SATO, S. E.; OLIVEIRA, A. M. S.; BARROS, E. J.; ALEIXO, A. A.; BAGATTINI, G. et al. Aspectos fisiográficos da paisagem guarulhense. In: OMAR, E. E. H. (Org.). Guarulhos tem história: questões sobre história natural, social e cultural. São Paulo: Ananda Gráfica e Editora, 2008b. 
ANDRIETTI, G.; FREIRE R.; DO AMARAL, A.G.; DE ALMEIDA F.T.; MILENE CARVALHO BONGIOVANI M. C. et al. Índices de qualidade da água e de estado trófico do rio Caiabi, MT. Revista Ambiente \& Água, v. 11, n. 1, p. 162-175, 2016. http://dx.doi.org/10.4136/ambi-agua.1769

AMERICAN PUBLIC HEALTH ASSOCIATION - APHA. Standard methods for the examination of water and wastewater. $21^{\text {st }}$ Ed. Washington, DC, 2012.

BAYRAM, A.; ÖNSOY, H.; BULUT, V. N.; AKINCI, G. Influences of urban wastewaters on the stream water quality: A case study from gumushane province, Turkey. Environmental Monitoring and Assessment, v. 185, n. 2, p. 1285-1303, 2013. http://dx.doi.org/10.1007/s10661-012-2632-y

BRAGA, R.; CARVALHO, P.F.C. Recursos hídricos e planejamento urbano e regional. Rio Claro: Laboratório de Planejamento Municipal, 2003. p. 113-127.

BOTELHO, R. G. M.; SILVA, A. S. Bacia hidrográfica e qualidade ambiental. In: VITTE, A. C.; GUERRA, A. J. T. Reflexões sobre a Geografia Física no Brasil. Rio de Janeiro: Bertrand Brasil, 2004. p. 153-192.

CAMPOS, D. C. Inundações: problemas ou fenômenos naturais? A ocupação das várzeas dos principais rios no Alto Tietê e a reprodução deste modelo urbano na Bacia do Rio Baquirivu Guacu. 2011. Dissertação (Mestrado em Análise Geoambiental) Universidade Guarulhos, Guarulhos, 2011.

CARvalho, A. de P.; BALDUINO, Â. R.; MACIEL, G. F.; PICANÇO, A. P. Avaliação da poluição em rios utilizando índices de qualidade da água: um estudo de caso no Ribeirão São João em Porto Nacional-TO. Geociências, v. 35, n. 3, p. 472-484, 2016.

COMPANHIA AMBIENTAL DO ESTADO DE SÃO PAULO - CETESB. Relatório de qualidade das águas superficiais do estado de São Paulo. Apêndice C: índice da qualidade da água. 2013. Available at: http://aguasinteriores.cetesb.sp.gov.br/wpcontent/uploads/sites/32/2013/11/Ap\%C3\%A Andice-C-\%C3\%8Dndices-de-Qualidade-das-\%C3\%81guas-.pdf. Access in: 25 Feb. 2017.

CONSELHO NACIONAL DO MEIO AMBIENTE - CONAMA. Resolução no 357 de 17 de março de 2005. Dispõe sobre a classificação dos corpos de água e diretrizes ambientais para o seu enquadramento, bem como estabelece as condições e padrões de lançamento de efluentes, e dá outras providências. Diário Oficial [da] União, Brasília, DF, 18 de março de 2005.

COSTA, M. L. R.; HENRY, R. Phosphorus, nitrogen, and carbon contents of macrophytes in lakes lateral to a tropical river (Paranapanema River, São Paulo, Brazil). Acta

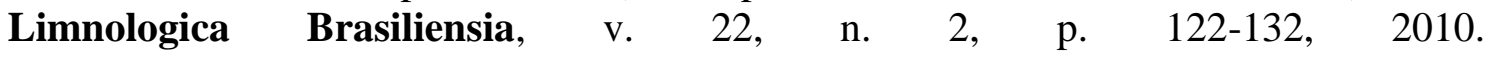
http://dx.doi.org/10.4322/actalb.02202002

DAS, R.; SAMAL, N. R.; ROY, P. K.; MITRA, D. Role of Electrical Conductivity as an Indicator of Pollution in Shallow Lakes. Asian Journal of Water. Environment and Pollution, v. 3, n. 1, p. 143-146, 2006.

DE AZEVEDO LOPES, F. W.; MAGALHÃES JUNIOR., A. P. M. Influência das condições naturais de $\mathrm{pH}$ sobre o índice de qualidade das águas (IQA) na bacia do Ribeirão de Carrancas. Geografias, v. 6, n. 2, p. 134-147, 2010. 
DERSA DESENVOLVIMENTO RODOVIÁRIO S/A. Empreendimentos. Available at: http://www.dersa.sp.gov.br/empreendimentos/GrupoEmpreendimento.aspx ?idGrupo=2. Access in: 2 July 2016.

DUVEILLER, G.; DEFOURNY, P.; DESCLÉE, B.; MAYAUX, P. Deforestation in Central Africa: estimates at regional, national and landscape levels by advanced processing of systematically distributed Landsat extracts. Remote Sensing of Environment, v. 112, p. 1969-1981, 2008. https://doi.org/10.1016/j.rse.2007.07.026

ENVIRONMENTAL SYSTEMS RESEARCH INSTITUTE - ESRI. ArcGIS Professional GIS for the desktop, version 10.0. Redlands, 2013.

ESTEVES, F. A. Fundamentos de Limnologia. 3. ed. Rio de Janeiro: Interciência, 2011.

FARAGE, J. A. P.; MATOS, A. T.; SILVA, D. D.; BORGES, A. C. Determinação do índice de estado trófico para fósforo em pontos do rio Pomba. Revista Engenharia na Agricultura, v. 18, n. 4, p. 322-329, 2010. https://doi.org/10.13083/reveng.v18i4.98

GAMA, A. M. C. de F. Avaliação da Agenda 21 da Bacia Hidrográfica do Rio Pirapama. 172 p. 2003. Dissertação (Mestrado em Gestão e Políticas Ambientais) - Universidade Federal de Pernambuco, Recife, 2003.

GRAÇA, B. A. Condicionantes geoambientais no processo histórico da ocupação territorial do município de Guarulhos, Estado de São Paulo. 2007. 147f. Dissertação (Mestrado em Análise Geoambiental) - Universidade Guarulhos, Guarulhos, 2007.

GRIECO, A. A; FREGONESI, B. M.; TONANI, K. A. A.; SIlVA, T. V.; CELERE, B. S.; TREVILATO, T. M. B. et al. Diagnóstico espacial e temporal de condições físicoquímicas e microbiológicas do Córrego do Tanquinho, Ribeirão Preto, SP, Brasil. Revista Ámbiente \& Água, v. 12, n. 2, p. 282-298, 2017. http://dx.doi.org/10.4136/1980-993X

INSTITUTO BRASILEIRO DE GEOGRAFIA E ESTATÍSTICA - IBGE. Manual Técnico de uso da Terra. 3. ed. Rio de Janeiro, 2013. 171 p. (Manuais técnicos em Geociências, n. 7).

KRUPEK, R. A.; BRANCO, C. C. Z.; PERES, C. K. Variação sazonal de alguns parâmetros físicos e químicos em três rios pertencentes a uma bacia de drenagem na região centrosul do Estado do Paraná, Sul do Brasil. Acta Scientiarum Biological Sciences, v. 30, n. 4, p. 431-438, 2008. http://dx.doi.org/10.4025/actascibiolsci.v30i4.5873

LAMPARELLI, M. C. Grau de trofia em corpos d'água do estado de São Paulo: avaliação dos métodos de monitoramento. 2004. 235f. Tese (Doutorado em Ecologia) Universidade de São Paulo, São Paulo, 2004.

MESQUITA, M. V. Degradação do meio físico em loteamento nos bairros Invernada, Fortaleza e Água Azul, como estudos de casos da expansão urbana do município de Guarulhos (SP). 2011. Tese (Doutorado) - Instituto de Geociências e Ciências Exatas, Universidade Estadual Paulista Júlio de Mesquita Filho, Rio Claro, 2011.

MIRANDA, M. J.; PINTO, H. S.; ZULLO JUNIOR, J.; FAGUNDES, R. M.; FONSECHI, D. B.; CALVE, L. et al. A classificação climática de Koeppen para o estado de São Paulo. Campinas: CEPAGRI; CPA,2009.

MOURA, L. H. A.; BOAVENTURA, G. R.; PINELLI, M. P. A qualidade da água como indicador de uso e ocupação do solo: Bacia do Gama-distrito Federal. Química Nova, v. 33, n. 1, p. 97-103, 2010. http://dx.doi.org/10.1590/S0100-40422010000100018 
MUELLER, C. H. Os economistas e as relações entre o sistema econômico e o meio ambiente. Brasília: Ed. UnB, 2007.

PANTANO, G.; GROSSELI, G. M.; MOZETO, A. A.; FADINI, P. S. Sustentabilidade no uso do fósforo: uma questão de segurança hídrica e alimentar. Química Nova, v. 39, n. 6, p. 732-740, 2016. http://dx.doi.org/10.5935/0100-4042.20160086

PEREIRA, B. W. de F.; MACIEL, M. D. N. M.; DE ASSIS OLIVEIRA, F.; DA SILVA ALVES, M. A. M.; RIBEIRO, A. M.; FERREIRA, B. M. et al. Uso da terra e degradação na qualidade da água na bacia hidrográfica do rio Peixe-Boi, PA, Brasil. Revista Ambiente \& Água, v. 11, n. 2, p. 472-485, 2016. http://dx.doi.org/10.4136/ambiagua. 1802

POMPÊO, M. L. M.; MOSCHINI-CARLOS, V. Macrófitas aquáticos e perifíton, aspectos ecológicos e metodológicos. São Carlos: Rima, 2003.POSSELT, E. L.; COSTA, A. B. Software IQAData 2010. 2010. Available at: http://www.unisc.br/ppgspi. Accessed on: 18 Oct. 2017.

PURANDARA, B. K.; VARADARAJAN, N.; VENKATESH, B.; CHOUBEY, V. K. Surface water quality evaluation and modeling of Ghataprabha River, Karnataka, India. Environmental Monitoring and Assessment, v. 184, p. 1371-1378, 2012. http://dx.doi.org/10.1007/s10661-011-2047

RIBEIRO, T.F.B. Reflexos do uso da terra na avaliação da poluição hídrica da bacia hidrográfica do Ribeirão das Lavras, Guarulhos - SP. 2016. Dissertação (Mestrado em Análise Geoambiental) - Universidade Guarulhos, Guarulhos, 2016.

RÍOS-VILLAMIZAR, E. A.; MARTINS JUNIOR, A. F.; WAICHMAN, A. V. Caracterização físico-química das águas e desmatamento na bacia do rio Purus, Amazônia Brasileira Ocidental. Revista Geografia Acadêmica, v. 5, n. 2, 2011.

SAAD, A. R.; VARGAS, R. R.; LOPES, J. C.; ARRUDA, R. de O. M.; De QUEIROZ, W. Índice de estado trófico da bacia hidrográfica do ribeirão Tanque Grande, Guarulhos (SP): análise comparativa entre as zonas rural e urbana. Geociências, v. 32, n. 4, p.611-624, 2013.

SANTOS, M. C. J. os impactos socioambientais gerados na ocupação urbana do bairro Jardins. São Cristóvão: UFS, 2011.

SÃO PAULO (Estado). Decreto $\mathrm{n}^{\circ} 10.755$, de 22 de novembro de 1977. Dispõe sobre o enquadramento dos corpos de água receptores na classificação prevista no Decreto $\mathrm{n}^{\circ}$ 8.468, de 8 de setembro de 1976, e dá providências correlatas. Diário Oficial [do] Estado de São Paulo, 1977.

SATO, S. E.; DOS SANTOS OLIVEIRA, A. M.; SAYAWA, S. B.; HERLING, T. B. R.; DE SOUSA MORETTI, R.; DA COSTA, G. L. et al. Estudo de Urbanização em Áreas de Risco a Escorregamentos nos Loteamentos do Recreio São Jorge e Novo Recreio, Região do Cabuçu, Guarulhos (SP), Brasil. Paisagem e Ambiente, v. 29, p. 57-82, 2011. http://dx.doi.org/10.11606/issn.2359-5361.v0i29p57-82

THOMPSON, M. Y.; BRANDES, D.; KNEY, A. D. Using electronic conductivity and hardness data for rapid assessment of stream water quality. Journal of Environmental Management, v. 104, p. 152-157, 2012. https://doi.org/10.1016/j.jenvman.2012.03.025 
TOMINAGA, L. K.; FERREIRA, C. J.; VEDOVELLO, R.; TAVARES, R.; SANTORO, J.; SOUZA, C. R. G. Cartas de perigo a escorregamentos e de risco a pessoas e bens do litoral norte de São Paulo: conceitos e técnicas. In: SIMPÓSIO BRASILEIRO DE CARTOGRAFIA GEOTÉCNICA E GEOAMBIENTAL, 5., 2004, São Carlos. Anais... São Carlos: SUPREMA, 2004. 12 p. v. 1.

TUCCI, C. E. M. Águas urbanas. Estudos Avançados, v. 22, n. 63, p. 97-112, 2008. http://dx.doi.org/10.1590/S0103-40142008000200007

UWIDIA, I. E.; UKULU, H. S. Studies on electrical conductivity and total dissolved solids concentration in raw domestic wastewater obtained from an estate in Warri, Nigeria. Greener Journal of Physical Sciences, v. 3, n. 3, p. 110-114, 2013.

VARGAS, R. R.; SAAD A. R.; DALMAS, F. B.; ROSA, A.; ARRUDA, R. O. M.; MESQUITA, M. V. et al. Water Quality Assessment in the Córrego Taquara do Reino Hydrographic Basin, Guarulhos Municipality (São Paulo State - Brazil): Effects of Environmental Degradation. Anuário do Instituto de Geociências, v. 38, n. 2, p. 137 $144,2015$.

VELP CIENTIFICA. BOD Analysis. Available at:

http://www.velp.com/en/products/lines/2/family/31/bod_analysis. Access in: 14 April 2016.

VON SPERLING, M. Introdução à qualidade das águas e ao tratamento de esgotos: princípios do tratamento biológico de águas residuárias. Belo Horizonte: DESA/UFMG, 2005. 